\title{
TANTANGAN DAN PELUANG PENDIDIKAN ISLAM DI ERA MEA
}

\author{
M. Ali Sibram Malisi \\ Dosen Pascasarjana IAIN Palangkaraya \\ Jln. G.Obos Komplek Islamic Center Palangka Raya
}

\begin{abstract}
Globalization is a process of integration of the national economies of Nations into a global economic system. Globalization also a cultural process which is characterized by the existence of a tendency of the regions in the world, both geographically as well as physically, being uniform in format of social, cultural, economic, and political. In social life, global process has created a culture of egalitarianism, in triggering the emergence of internationalization of culture, creating economic interdependence in the process of production and marketing, and in the field of political liberalization creates. Although globalization campaigned as the era of the future, a promising era of ' economic growth ' will bring globally and global prosperity for all.

The challenge of national education is growing. Because in the era of the MEA challenge is one of the free flow of skilled workforce ASEAN cross country. If a resource teacher in Indonesia still covered a variety of flaws at both aspects of the competency, qualification, productivity, and well-being, then they can be marginalized in regional and global competition. To that end, the efforts of professional development teachers need to touch up the most fundamental aspects in a change of their competencies.
\end{abstract}

\section{PENDAHULUAN}

Globalisasi merupakan suatu proses pengintegrasian ekonomi nasional bangsa-bangsa ke dalam suatu sistem ekonomi global. Ia juga merupakan proses kebudayaan yang ditandai dengan adanya kecenderungan wilayah-wilayah di dunia, baik geografis maupun fisik, menjadi seragam dalam format sosial, budaya, ekonomi, dan politik. Dalam kehidupan sosial, proses global telah menciptakan egalitarianisme, di bidang budaya memicu munculnya internationalization of culture, di bidang ekonomi menciptakan saling ketergantungan dalam proses produksi dan pemasaran, dan di bidang politik menciptakan liberalisasi. Meskipun globalisasi dikampanyekan sebagai era masa depan, yakni suatu era yang menjanjikan pertumbuhan ekonom 
secara global dan akan mendatangkan kemakmuran global bagi semua Tantangan pendidikan nasional bertambah karena pada era MEA salah satu tantangannya adalah arus bebas tenaga kerja terampil lintas negara ASEAN. Jika sumber daya guru di Indonesia masih diliputi berbagai kelemahan baik pada aspek kompetensi, kualifikasi, produktivitas, dan kesejahteraan, maka mereka dapat tersisih dalam persaingan regional maupun global. Untuk itu, upaya pengembangan profesionalisme guru harus menyentuh sampai aspek yang paling fundamental dalam perubahan kompetensi mereka.

Salah satu fungsi utama pendidikan islam menanamkan ajaran Islam ke dalam kehidupan masyarakat, dalam perjalanan sejarahnya selain dipengaruhi oleh faktor sosial, ekonomi, politik dan kultural keagamaan, juga dihadapkan dengan berbagai tantangan. Atas dasar fakta demikian, maka sungguhpun rujukan utama pendidikan Islam itu adalah al-Qur'an dan Hadits, namun dalam implementasinya menunjukkan dinamika dan variasi yang amat beragam. Al Ainain (1980:37) ${ }^{1}$ dalam kaitan ini menegaskan bahwa pendidikan sebagai sebuah kegiatan yang bersifat sosial kemasyarakatan yang kehadirannya selalu berbeda-beda sesuai dengan corak, sifat dan kebudayaan yang berkembang pada masyarakat tersebut.

$\mathrm{Nata}^{2}$ mengatakan bahwa tantangan pendidikan Islam sekarang ini amat beragam demikian juga respon dan kesanggupan masyarakat untuk menghadapi tantangan tersebut amat beragam pula. Sejarah mencatat bahwa di antara lembaga- lembaga pendidikan Islam yang di masa dahulu menunjukkan kejayaan dan disegani masyarakat, hingga sekarangpun tetap jaya dan disegani masyarakat. Namun ada pula lembaga yang dahulu keredibilitasnya demikian tinggi, namun sekarang kurang terdengar lagi, bahkan nyaris tenggelam. Keadaan yang demikian itu amat tergantung kepada sejauh mana lembaga pendidikan dengan sumber daya manusia yang ada di dalamnya mampu mengatasi berbagai tantangan yang muncul.

\footnotetext{
${ }^{1}$ Ali al-Khalil Abu al-Ainain, Falsafah al-Tarbiyah al-Islamiyah di al-Qur"anul Karim, (Beirut: Dar al-Fikr al-Arabiyah, 1980), h. 37.

${ }^{2}$ Abuddin Nata, Pendidikan Islam di Indonesia: Tantangan dan Peluang, (Jakarta: UIN Jakarta, 2004), h. 2.
} 
Keberhasilan suatu pembangunan termasuk pendidikan selalu disertai dengan tantangan-tantangan baru dan bahkan dampak negatifnya sekaligus. Sebagai antisipasi diperlukan respon dan perlakuan baru yang lebih baik, termasuk dalam hal pendidikan Islam sangat diperlukan konsep pendidikan baru yang lebih Islami. Upaya mencari paradigma baru pendidikan semakin menjadi obsesi semua kalangan, karena seluruh proses kehidupan identik dengan proses pendidikan. Di samping itu, urgensi mencari dan menemukan paradigm pendidikan baru yang semakin islami itu ditentukan pula oleh kondisi objektif dunia saat ini di mana moral telah benar-benar dikesampingkan sebagai bagian esensial dari kehidupan manusia. ${ }^{3}$

Dalam kaitan dengan persoalan di atas, maka tantangan yang bersifat mendasar terhadap sistem pendidikan Islam antara lain :

1. Mampukah sistem pendidikan Islam menjadi centre of excellence bagi perkembangan ilmu pengetahuan dan teknologi (Iptek) yang tidak bebas nilai.

2. Mampukah sistem pendidikan menjadi agen pembaruan pemikiran Islam yang responsif terhadap tantangan zaman tanpa mengabaikan aspek dogmatis yang wajib diikuti.

3. Mampukah Pendidikan Islam menumbuhkembangkan kepribadian yang benarbenar beriman dan bertakwa kepada Allah lengkap dengan kemampuan bernalar ilmiah yang tidak mengenal batas akhir.

Globalisasi merupakan suatu proses pengintegrasian ekonomi nasional bangsa-bangsa ke dalam suatu sistem ekonomi global. Ia juga merupakan proses kebudayaan yang ditandai dengan adanya kecenderungan wilayah-wilayah di dunia, baik geografis maupun fisik, menjadi seragam dalam format sosial, budaya, ekonomi, dan politik. Dalam kehidupan sosial, proses global telah menciptakan egalitarianisme, di bidang budaya memicu munculnya internationalization of culture, di bidang ekonomi menciptakan saling ketergantungan dalam proses produksi dan pemasaran, dan di bidang politik menciptakan liberalisasi. Jika ditinjau dari sejarah perkembangan ekonomi, globalisasi pada dasarnya merupakan salah satu fase perjalanan panjang perkembangan kapitalisme liberal yang secara teoritis sebenarnya telah

\footnotetext{
${ }^{3}$ Mastuhu, Memberdayakan Pendidikan Islam, (Jakarta: Logos Wacana Ilmu, 1999), h. xi
} 
dikembangkan oleh Adam Smith. Meskipun globalisasi dikampanyekan sebagai era masa depan, yakni suatu era yang menjanjikan 'pertumbuhan' ekonomi secara

global dan akan mendatangkan kemakmuran global bagi semua, globalisasi sesungguhnya adalah kelanjutan dari kolonialisme dan developmentalisme sebelumnya. ${ }^{4}$

Tantangan pendidikan nasional bertambah. Karena pada era MEA salah satu tantangannya adalah arus bebas tenaga kerja terampil lintas negara ASEAN. Jika sumber daya guru di Indonesia masih diliputi berbagai kelemahan baik pada aspek kompetensi, kualifikasi, produktivitas, dan kesejahteraan, maka mereka dapat tersisih dalam persaingan regional maupun global. Untuk itu, upaya pengembangan profesionalisme guru harus menyentuh sampai aspek yang paling fundamental dalam perubahan kompetensi mereka. ${ }^{5}$

Menghadapi Masyarakat Ekonomi Asia (MEA) Perguruan Tinggi dituntut dapat lebih meningkatkan kualitas lulusannya yang memiliki kemampuan di dunia

kerja. Skema AEC 2015 tentang ketenagakerjaan, misalnya, memberlakukan

liberalisasi tenaga kerja profesional, seperti dokter, insinyur, akuntan, guru, dosen dan lain sebagainya. Amin Haedari menunjukkan data jumlah siswa yang ada di Indonesia mencapai angka 44 jutaan siswa diperkirakan jumlah siswa muslim berjumlah 40 jutaan siswa. Sementara jumlah siswa siswa yang ada di madrasah Ibtidaiyah sampai dengan Aliyah mencapai 8 jutaan siswa.jumlah ini sangat besar, tantangannya di era MEA adalah siswa-siswa ini calon pemimpin bangsa dan akan mengisi posisi-posisi strategis di Republik Indonesia. Mereka harus mendapatkan pendidikan agama yang baik. sebaliknya jika sektor tersebut tidak diisi oleh generasi yang tidak mendapatkan pendidikan agama yang baik, tentu akan menjadi ancaman. Sementara, data guru pendidikan agama Islam h.

4 Moh. Ali Aziz, Tantangan Pendidikan Islam di Era Global, dalam Jurnal Tarbawiyah, 1-6, Program Pascasarjana STAI Al-Khoziny.

${ }_{5}$ Andi Prastowo, Perubahan Mindset dan Kesiapan Guru Sekolah Dasar dalam

Pendidikan di Era MEA, Prosiding Seminar Nasional Pendidikan Ekonomi UNY. 
hanya berjumlah 182 ribu dan akan pensiun sekitar 20 ribu. Dari jumlah guru yang sangat sedikit ini tentu menjadi tugas besar dalam melakukan perubahan dan memberikan pendidikan agama Islam yang baik. Sedangkan data lapisan pekerjaan dilihat dari tingkat pendidikan menunjukkan bahwa usia di atas 15 tahun pada semua sektor pekerjaan masih didominasi oleh tenaga kerja lulusan pendidikan dasar (SD) sebesar 46,8\%, lulusan SMP 17\%, SMA sederajat 25\% dan Perguruan Tinggi 10,14\%. ${ }^{6}$

\section{LANDASAN TEORI}

\section{Paradigma Islam Tentang Tantangan dan Peluang Pendidikan}

Dalam kehidupan sekarang ini kita menyadari bahwa munculnya peradaban modern-industrial yang dipercepar oleh era globalisasi merupakan rangkaian dari kemajuan Barat pasca-renaissance yang membawa nilai antroposentrisme dan humanisme sekuler. Paham yang mendewakan kedigjayaan manusia dan dunia secara faktual ini mengakibatkan munculnya banyak persoalan kemanusiaan dalam bentuk krisis moral, krisis spiritual dan krisis kebudayaan dalam kehidupan

manusia. ${ }^{7}$ Dalam kerangka melihat persoalan umat manusia yang cukup serius berkaitan dengan kemodernan dan era globalisasi inilah maka amat perlu dilakukan upaya reaktualisasi pemikiran keagamaan yang mampu memberikan arah sekaligus nilai dan kerangka berpikir yang tepat dalam kehidupan manusia. Paradigma al-Qur'an sebagai suatu konstruksi pengetahuan bisa memungkinkan untuk memahami realitas sosial sebagaimana al-Qur'an sendiri memahaminya. Al-Qur'an membangun konstruksi pengetahuan agar kita memiliki -hikmah yang atas dasar itu dapat dibentuk perilaku yang sejalan dengan nilai-nilai normative baik pada level moral maupun sosial. ${ }^{8}$

Pentingnya penggunaan akan budi dan hati nurani manusia telah diperintahkan al-Qur'an melalui perintah Iqra dalam surat al-Alaq 1-5 kaitannya

${ }^{6}$ Amin Haedari, MEA, Tantangan dan Peluang Guru Pendidikan Agama Islam, http://iainptk.ac.id/mea-tantangan-dan-peluang-guru-pendidikan-agama-islam.

${ }^{7}$ Haidar Nashir, Agama dan Krisis Kemanusiaan Modern, (Yogyakarta: Pustaka Pelajar, 1997), h. 176.

\footnotetext{
${ }^{8}$ Kuntowijoyo, Paradigma Islam Interpretasi untuk Aksi, Bandung: Mizan, 1999), h. 327.
} 
bahwa era globalisasi sekarang ini merupakan suatu masa yang penuh tantangan untuk mewujudkan suatu masyarakat akademik, masyarakat yang berkembang menuju knowledge society dengan ciri utama adanya persaingan bebas dengan berlandaskan bahwa kesuksesan sangat ditentukan oleh educated person, orang yang terus mencari ilmu untuk merebut dan menguasai sains dan teknologi dengan mengandalkan akal dan pikiran.

Demikian pula Suyanto (2000) mengemukakan bahwa dalam kehidupan sekarang ini amat perlu membangun masyarakat sadar akan belajar (learning society). learning society merupakan sendi dasar yang amat penting dalam meningkatkan gairah kompetisi di dalam era globalisasi. Dari kenyataan inilah maka sangat perlu dikembangkan tiga tuntutan terhadap kualitas sumber daya manusia di era globalisasi, yaitu (1) SDM yang unggul; (2) adanya manusia yang terus menerus belajar; (3) perlunya dikembangkan nilai-nilai yang sesuai bagi kehidupan manusia

di abad ke $21 .^{9}$

\section{Peluang Pendidikan Islam}

Peluang pendidikan Islam seharusnya bisa ditangkap, diraih dan dimanfaatkan oleh para pemerhati pendidikan dalam rangka pelaksanaan dan

implementasi nilai dan tujuan untuk menyongsong masa depan yang penuh kompetisi ditandai dengan munculnya era Masyarakat Ekonomi Asean. Adapun peluang pendidikan Islam bisa dideskripsikan di antaranya :

1. Peningkatan fungsi dan peranan. Seperti kita ketahui beberapa tahun belakangan fungsi dan peran pendidikan Islam sangat terbatas, dan kadangkadang terjadi diskriminasi. Outputnya tidak dapat diterima pada jenjang tertentu atau kemampuannya diragukan pada lapangan kerja tertentu. Namun sejak diberlakukannya UU No. 20 Tahun 2003 tentang Sistem Pendidikan Nasional dengan berbagai peraturan penjabarannya, fungsi dan peran lembaga pendidikan Islam mulai dari tingkat dasar hingga perguruan tinggi sudah

${ }^{9}$ Suyanto, Refleksi dan Reformasi Pendidikan Islam di Indonesia, (Yogyakarta: Adicita Karya

Nusa, 2000), h. vii 
diperluas bahkan sudah terbuka lebar. Karena itu, peluang ini harus diraih dan didayagunakan oleh segenap potensi penyelenggara pendidikan Islam.

2. Peningkatan persaingan dan antisipasi agama. Selaras dengan era globalisasi, di mana pemikiran manusia semakin kompleks dan menimbulkan kebingungan dalam masyarakat, perlu adanya pendekatan sosialisasi dan internalisasi nilai-nilai agama. Namun persoalannya, dalam kondisi yang serba rasionalis, orang menjadi tidak mudah mengambil konsep agama secara komprehensif, baik kepada peserta didik maupun kepada masyarakat luas.

3. Pengembangan kelembagaan. Kesempatan meningkatkan fungsi dan peranan lembaga pendidikan Islam dalam pengembangan dan pembinaan masyarakat seharusnya mendorong umat Islam bisa mengelola pendidikan Islam dengan lebih baik sesuai dengan perkembangan zaman. Dalam hal ini ada dua sasaran utama, yaitu perluasan bidang garapan dan peningkatan kualitas proses serta output hasil pendidikan. Peluang ini harus dimanfaatkan sebaik-baiknya, sebab bila tidak maka lembaga pendidikan Islam tidak akan mampu berkompetisi yang akhirya akan ditinggalkan umat.

4. Kerjasama. Di era globalisasi yang penuh kompetisi, sangat sulit bagi suatu lembaga pendidikan dapat berjalan dan berkembang sendiri tanpa mau terlibat dan melibatkan pihak lain. Ini berarti solusi utamanya adalah harus mampu menciptakan kerjasama kelembagaan yang saling menguntungkan.

Terdapat empat hal yang akan menjadi fokus MEA pada tahun 2015 yang dapat dijadikan suatu momentum yang baik untuk Indonesia. Pertama, negaranegara di kawasan Asia Tenggara ini akan dijadikan sebuah wilayah kesatuan pasar dan basis produksi. Kedua, MEA akan dibentuk sebagai kawasan ekonomi dengan tingkat kompetisi yang tinggi, yang memerlukan suatu kebijakan yang meliputi competition policy, consumer protection, Intellectual Property Rights (IPR), taxation, dan E-Commerce. Dengan demikian, dapat tercipta iklim kompetisi yang adil. Ketiga, MEA pun akan dijadikan sebagai kawasan yang memiliki perkembangan ekonomi yang merata, dengan memprioritaskan pada Usaha Kecil Menengah (UKM). Keempat, MEA akan diintegrasikan secara penuh terhadap perekonomian global. Berdasarkan ASEAN Economic Blueprint, MEA menjadi sangat dibutuhkan 
untuk memperkecil kesenjangan antara negara-negara ASEAN dalam hal pertumbuhan perekonomian dengan meningkatkan ketergantungan anggotaanggota di dalamnya. MEA dapat mengembangkan konsep meta-nasional dalam rantai suplai makanan, dan menghasilkan blok perdagangan tunggal yang dapat menangani dan bernegosiasi dengan eksportir dan importir non-ASEAN. ${ }^{10}$

\section{Tantangan Pendidikan Islam}

Tantangan yang dihadapi oleh pendidikan Islam harus diantisipasi agar pendidikan bisa dilaksanakan dan diimplementasikan sesuai dengan misi dan

tujuannya. Jika suatu tantangan mampu diantisipasi atau dihadapi dengan baik, seringkali tantangan itu menjadi peluang yang sangat berdaya guna, sebaliknya jika

tidak mampu dihadapi dengan baik, seringkali ia menjadi kendala yang sangat mengganggu upaya pelaksanaan dan implementasi misi dan tujuan pendidikan Islam.

Tantangan pendidikan Islam terus bergulir sejak masa Orde Lama hingga masa reformasi sekarang ini. Tantangan yang sekarang dihadapi adalah sejalan dengan peran yang harus dimanfaatkan oleh umat Islam untuk ikut serta terlibat dalam melakukan penataan ulang seluruh aspek kehidupan, baik di bidang ekonomi, sosial, politik, budaya, pendidikan dan sebagainya menurut cara-cara yang lebih demokratis, transparan, berkeadilan, jujur, amanah, manusiawi dan modern melalui konsep masyarakat madani yang berbasis al-Qur'an dan Sunnah Nabi. Tantangan lainnya yang dihadapi pendidikan islam adalah berkaitan dengan dampak yang ditimbulkan oleh globalisasi dunia yang didukung oleh kemajuan ilmu pengetahuan dan teknologi, khususnya teknologi informasi dan komunikasi.

Kehidupan masa mendatang yang ditandai oleh kemajuan ilmu pengetahuan dan teknologi dengan dampak yang bersifat multidimensional mengharuskan pendidikan Islam supaya bisa melahirkan manusia yang mampu menjalani kehidupan (preparing children for life), dan bukan hanya sekedar

\footnotetext{
${ }^{10}$ Arya Baskoro, Peluang, Tantangan dan Risiko bagi Indonesia dengan Adanya Masyarakat

Ekonomi Asean, Centre for Risk Management Studies
} 
anak didik yang dapat bekerja. Pendidikan Islam harus mampu melahirkan manusia yang berorientasi ke masa depan, bersikap progresif, mampu memilih dan memilah secara baik, dan membuat perencanaan dengan baik. Pendidikan Islam juga harus mampu menghasilkan anak didik yang memiliki keseimbangan antara penggunaan otak kiri dengan otak kanan.

Lulusan pendidikan yang dihasilkan lembaga pendidikan Islam di masa sekarang dan masa yang akan datang adalah bukan sekedar anak yang mengetahui sesuatu (learning to know) melainkan juga dapat mengamalkan secara benar (learning to do), mempengaruhi dirinya (learning to be), dan membangun kemitraan dengan sesama (learning to live together). Pendidikan Islam harus menghasilkan manusia yang memiliki ciri-ciri sebagai berikut: (1) terbuka dan bersedia menerima hal-hal baru hasil inovasi dan perubahan; (2) berorientasi demokratis dan mampu memiliki pendapat yang tidak selalu sama dengan orang lain; (3) berpijak pada kenyataan, menghargai waktu, konsisten dan sistematik dalam menyelesaikan masalah; (4) selalu terlibat dalam perencanaan dan pengorganisasian; (5) memiliki keyakinan bahwa segalanya dapat diperhitungkan; (6) menghargai pendapat orang lain; (7) rasional dan percaya pada kemampuan Iptek; (8) menjunjung tinggi keadilan berdasarkan prestasi, efektifitas dan efisiensi.

Abuddin Nata mengemukakan tantangan-tantangan yang dihadapi pendidikan Islam di era kekinian menghadapi pertarungan ideologi-ideologi besar dunia ditandai oleh lima kecenderungan sebagai berikut:

1. Kecenderungan integrasi ekonomi yang menyebabkan terjadinya persaingan bebas dalam dunia pendidikan. Munculnya konsep pendidikan yang berbasis pada sistem dan infra-struktur, manajemen berbasis mutu terpadu (TQM), interpreneur university dan lahirnya Undang-undang Badan Hukum Pendidikan (BHP) tidak lain, karena menempatkan pendidikan sebagai komoditi yang diperdagangkan.

2. Kecenderungan fragmentasi politik yang menyebabkan terjadinya peningkatan tuntutan dan harapan dari masyarakat. Mereka semakin membutuhkan perlakuan yang adil, demokratis, egaliter, transparan, akuntabel, cepat, tepat dan profesional. Mereka ingin dilayani dengan baik dan memuaskan. Kecenderungan ini terlihat dari adanya pengelolaan manajemen pendidikan yang berbasis sekolah (shool 
based manajemen), pemberian peluang kepada komite atau majelis sekolah/madrasah untuk ikut dalam perumusan kebijakan dan program pendidikan, pelayanan proses belajar mengajar yang lebih memberikan peluang dan kebebasan kepada peserta didik, yaitu model belajar mengajar yang partisipatif, aktif, inovatif, kreatif, efektif dan menyenangkan (Paikem).

3. Kecenderungan penggunaan teknologi tinggi (high technologie) khususnya teknologi komunikasi dan informasi (TKI) seperti komputer. Kehadiran TKI ini menyebabkan terjadinya tuntutan dari masyarakat untuk mendapatkan pelayanan yang lebih cepat, transparan, tidak dibatasi waktu dan tempat.

4. Kecenderungan interdependensi (saling tergantungan), yaitu suatu keadaan di mana seseorang baru dapat memenuhi kebutuhannya apabila dibantu oleh orang lain.

5. kecenderungan munculnya penjajahan baru dalam bidang kebudayaan (new colonization in culture) yang mengakibatkan terjadinya pola pikir (mindset) masyarakat pengguna pendidikan, yaitu dari yang semula mereka belajar dalam rangka meningkatkan kemampuan intelektual, moral, fisik dan psikisnya, berubah menjadi belajar untuk mendapatkan pekerjaan dan penghasilan yang besar. Saat ini sebelum seseorang belajar atau masuk kuliah misalnya, terlebih dahulu bertanya: nanti setelah lulus bisa jadi apa? Dan berapa gajinya? programprogram studi yang tidak dapat menjawab pertanyaan tersebut baik secara langsung maupun tidak langsung, dengan sendirinya akan terpinggirkan atau tidak diminati. Sedangkan program-program studi yang menawarkan pekerjaan dan penghasilan yang baik bagi lulusannya akan sangat diminati. Tidak hanya itu, kecenderungan penjajahan baru dalam bidang kebudayaan juga telah menyebabkan munculnya budaya pop atau budaya urban, yaitu budaya yang serba hedonistik, materialistik, rasional, ingin serba cepat, praktis, pragmatis dan instans. Kecenderungan budaya yang demikian itu menyebabkan ajaran agama yang bersifat normatif dan menjanjikan masa depan yang baik (di akhirat) kurang diminati. Mereka menuntut ajaran agama yang sesuai dengan budaya pop dan budaya urban. Dalam keadaan demikian, tidaklah mengherankan jika mata pelajaran agama yang disajikan secara normatif dan konvensional output menjadi tidak menarik dan ketinggalan zaman. Keadaan ini mengharuskan para 
guru atau ahli agama untuk melakukan reformulasi, reaktulisasi, dan kontekstualisasi terhadap ajaran agama, sehingga ajaran agama tersebut akan terasa efektif dan transformatif. ${ }^{11}$

Dalam menjawab tantangan di atas bahwa sejalan dengan arah dan visi pendidikan Islam, maka berbagai komponen pendidikan seperti kurikulum, fungsi guru, bahan ajar, proses belajar mengajar, media pengajaran, evaluasi, manajemen, lingkungan, pola hubungan guru murid, biaya pendidikan dan sebagainya harus ditata ulang. Kurikulum pendidikan harus diarahkan pada terlaksananya Kurikulum 2013 yang menekankan pada output pendidikan yang memiliki kompetensi yang dapat diukur melalui indicator-indikator yang terkait dengan itu. Sedangkan bahan ajar harus disesuaikan dengan program studi dan pasar tenaga kerja, sehingga antara lulusan pendidikan dan pasaran tenaga kerja terjadi hubungan yang saling terkait. Bersamaan dengan itu, proses belajar mengajar pun harus diarahkan pada proses belajar mengajar yang memberdayakan para siswa dengan pendekatan yang memusat pada anak didik (student centris), dan bukan berpusat pada guru (teacher centris). Model pembelajaran Cara Belajar Siswa Aktif (CBSA), Quantum Teaching dari Boby de Porter, Problem Based Learning, Cooperative Learning, Interactive Learning dan semacamnya harus mengganti model belajar hafalan yang bertumpu pada guru. Dengan kata lain, proses belajar mengajar yang dilakukan adalah proses belajar mengajar yang mencerahkan nalar (inspiring teaching) anak didik. Proses belajar mengajar juga harus diarahkan pada hal-hal berikut: (1) mengubah cara belajar dari warisan kepada model pemecahan masalah; (2) dari hafalan ke dialog; (3) dari pasif ke aktif; (4) dari memiliki (to have) ke menjadi (to be); (5) dari mekanis ke kreatif; (6) dari menguasai materi sebanyak-banyaknya ke menguasai metodologi yang kuat; (7) dari memandang dan menerima ilmu sebagai yang berada dalam dimensi proses; dan (8) melihat fungsi pendidikan bukan hanya mengasah dan mengembangkan akal, melainkan juga mengolah dan mengembangkan hati (moral dan keterampilan). Seiring dengan terjadinya perubahan paradigma guru pun harus mengalami perubahan pula. Keadaan guru di era globalisasi ini bukan satu-satunya penyalur ilmu pengetahuan dan

${ }^{11}$ Abuddin Nata, Tantangan dan Peluang Pendidikan Islam di Era Globalisasi, https://saepudinonline.wordpress.com/2012/12/17 
informasi, melainkan hanya salah satunya saja. Guru di masa sekarang harus berfungsi sebagai motivator, dinamisator, evaluator, justifikator. Pola hubungan antara guru dan murid seharusnya sebagai mitra yang interaktif. Untuk dapat mewujudkan paradigma tersebut, aspek manajemen pendidikan pun harus pula dibenahi. Untuk ini paling kurang terdapat tiga pilihan manajemen pendidikan yang dapat dipergunakan. Pertama, Total Quality Management (TQM) yang menekankan produktivitas berdasarkan teamwork yang solid dan leadership yang handal. Kedua, benchmarking management yang mendasarkan pada teori yang mengatakan bahwa untuk meningkatkan mutu produksi harus didasarkan pada standarisasi mutu yang baku, sehingga tujuan produksi menjadi jelas. Ketiga, school based management yang mendasarkan pada teori bahwa proses pengambilan keputusan dan perumusan tujuan pendidikan yang selama ini dilakukan oleh otoritas pusat harus didelegasikan kepada pelaksana di lapangan, yakni sekolah. Dengan cara demikian, efektifitas dan efisiensi pencapaian tujuan lebih dapat dipertanggungjawabkan. ${ }^{12}$

\section{HASIL PENELITIAN DAN PEMBAHASAN}

\section{Reaktualisasi Konsep Dasar Pendidikan Islam Dalam Menjawab Peluang dan Tantangan Pendidikan}

Tilaar $^{13}$ berpendapat bahwa abad ke 21 adalah abad perubahan besar di dalam kehidupan manusia, masyarakat abad ke-21 merupakan masyarakat transisi.

Perubahan itu berdasarkan kehidupan agraris ke masyarakat industry dan informasi dengan kehidupan yang berbeda, dan diperbesar lagi dengan adanya gelombang

globalisasi.

Watik Pratiknya sebagaimana dikutip Faj ar, ${ }^{14}$ menggambarkan corak masyarakat yang berkembang di masa sekarang dan masa akan datang adalah

${ }^{12}$ Abuddin Nata, Pendidikan Islam di Indonesia.., h. 11-12.

${ }^{13}$ H.A.R. Tilaar, Beberapa Aspek Reformasi Pendidikan Nasional dalam Perspektif Abad 21, (Magelang: Indonesia Tiara, 1999), h. 30:39

${ }^{14}$ A. Malik Fadjar, Reorientasi Pendidikan Islam, (Jakarta: Fajar Dunia, 1999), h. 77-78 
berkembangnya penggunaan teknologi di dalam kehidupan, tumbuhnya masyarakat

sadar informasi, adanya perilaku fungsional dan juga kehidupan menjadi semakin sistemik dan terbuka. Untuk itulah pendidikan yang akan datang mesti pendidikan yang strategis yang mampu memberikan kemampuan teknologis, fungsional, individual, informative dan terbuka.

Dalam era globalisasi ini niscayanya proses modernisasi terjadi dalam kehidupan manusia, karena berbagai pemenuhan tuntutan manusia dan perkembangan kemajuan bidang-bidang iptek, terutama dalam dunia informasi dan inovasi baru yang membawa perubahan drastis. Menghadapi keadaan yang demikian, pendidikan Islam pun mesti berupaya meletakkan posisinya kepada kedudukan yang strategis bukan saja dalam rangka membangun manusia yang utuh menyeluruh, melainkan juga menanamkan nilai-nilai yang ideal bagi kehidupan dan kemajuan masyarakat yang dinamis berkembang agar mampu memberikan pemecahan terhadap berbagai persoalan yang timbul sebagai akibat dari kemajuan iptek, modernisasi dan globalisasi. Selain itu, pendidikan Islam juga diharapkan mampu membangun konstruksi corak keilmuan dan teknologi yang integrative

(antara spritualisme dan realism) dalam kehidupan. Pendidikan juga merupakan lembaga yang terbaik dalam membimbing kehidupan manusia untuk mewujudkan aktualisasi dirinya bagi kehidupan yang utuh dan sejahtera sesuai dengan cita-cita kehidupan. Kesemuanya ini tentu saja tidak bisa lepas dari konsep ketuhanan, kemanusiaan dan kealaman yang dikembangkan secara integratif.

Selanjutnya Fadjar ${ }^{15}$ yang mengutip pendapat Ahmad Pratiknya mengemukakan bahwa sumber daya manusia yang berkualitas menyangkut tiga dimensi: (1) dimensi ekonomi, (2) dimensi budaya, dan (3) dimensi spiritual (iman dan takwa). Upaya mengembangkan kualitas manusia lewat pendidikan perlu mengacu pada nilai tambah dari ketiga dimensi di atas, yakni nilai tambah ekonomis, nilai tambah budaya dan nilai tambah spiritual. Dalam kerangka inilah pendidikan Islam sebagai proses pengembangan manusia secara

\footnotetext{
${ }^{15}$ A. Malik Fadjar, Reorientasi Pendidikan ..., h. 34.
} 
makro meliputi beberapa proses yaitu proses pembudayaan, proses pembinaan iman dan takwa (imtak) dan proses pembinaan iptek. Sejalan dengan inilah pendidikan Islam dalam pengembangan sumber daya manusia secara mikro merupakan proses transfer of knowledge, transfer of methodology, dan transfer of value.

Selain itu, setiap muslim perlu menyadari dan meyakini sepenuhnya bahwa kebenaran Islam sebagai way of life, nilai-nilai dasarnya terkandung dalam kitab suci al-Qur'an sebagai wahyu Allah. Kemajuan modernisasi di sini harus dikembangkan atas dasar: (1) Allah menciptakan seluruh alam dengan haq bukan bathil (QS.16:3, 38:27; (2) Dia mengaturnya dengan segala peraturan Ilahi (Sunnatullah) yang menguasai dan pasti (QS. 7:54, 25:2), (3) sebagai ciptaan.

\section{KESIMPULAN}

Dari uraian di atas dapat disimpulkan bahwa peluang dan tantangan pendidikan Islam di Era MEA sebenarnya amat kompleks. Demikian pula respon dan kesanggupan masyarakat untuk menghadapi tantangan tersebut. Paradigm alQur'an tentang pendidikan bisa digunakan sebagai perumusan teori, dalam pengertian suatu konstruksi pengetahuan yang memungkinkan untuk memahami realitas. Peluang pendidikan Islam bisa meliputi: peningkatan fungsi dan peranan, peningkatan persaingan dan antisipasi agama, pengembangan kelembagaan, dan kerjasama. Tantangan pendidikan Islam yang sekarang dihadapi adalah aspek-aspek kehidupan yang meliputi faktor-faktor ekonomi, politik, sosial, budaya, pendidikan dan sebagainya, yang dituntut untuk diimplementasikan menurut cara-cara yang lebih demokratis, transparan, berkeadilan, jujur, amanah, manusiawi dan modern sesuai dengan konsep masyarakat madani yang berbasis al-Qur'an dan Sunnah Nabi. 


\section{DAFTAR PUSTAKA}

Al-Ainain, Ali al-Khalil Abu, Falsafah al-Tarbiyah al-Islamiyah di alQur"anul Karim, Beirut: Dar al-Fikr al-Arabiyah, 1980.

Arya Baskoro, Peluang, Tantangan dan Risiko bagi Indonesia dengan Adanya Masyarakat Ekonomi Asean, Centre for Risk Management Studies.

Aziz, Moh. Ali, -Tantangan Pendidikan Islam di Era Global, dalam Jurnal Tarbawiyah, h. 1-6, Program Pascasarjana STAI Al-Khoziny. Fadjar, A. Malik, Reorientasi Pendidikan Islam, Jakarta: Fajar Dunia, 1999.

H.A.R. Tilaar, Beberapa Aspek Reformasi Pendidikan Nasional dalam Perspektif Abad 21, Magelang: Indonesia Tiara, 1999.

Haedari, Amin, MEA, Tantangan dan Peluang Guru Pendidikan Agama Islam, http://iainptk.ac.id/mea-tantangan-dan-peluang-guru-pendidikanagama-islam.

Kuntowijoyo, Paradigma Islam Interpretasi untuk Aksi, Bandung: Mizan, 1999.

Mastuhu, Memberdayakan Pendidikan Islam, Jakarta: Logos Wacana Ilmu, 1999. Nashir, Haidar, Agama dan Krisis Kemanusiaan Modern, Yogyakarta: Pustaka Pelajar, 1997.

Nata, Abuddin, Pendidikan Islam di Indonesia: Tantangan dan Peluang, Jakarta: UIN Jakarta, 2004.

Nata, Abuddin, Tantangan dan Peluang Pendidikan Islam di Era Globalisasi, https://saepudinonline.wordpress.com/2012/12/17.

Prastowo, Andi, Perubahan Mindset dan Kesiapan Guru Sekolah Dasar dalam Persaingan Pendidikan di Era MEA, Prosiding Seminar Nasional Pendidikan Ekonomi UNY.

Suyanto, Refleksi dan Reformasi Pendidikan Islam di Indonesia, Yogyakarta: Adicita Karya Nusa, 2000 